\title{
ANALYSIS OF COBALT, TANTALUM, TITANIUM, \\ VANADIUM AND CHROMIUM IN TUNGSTEN CARBIDE BY \\ INDUCTIVELY COUPLED PLASMA-OPTICAL EMISSION \\ SPECTROMETRY
}

\author{
Submitted in partial fulfilment of the requirements \\ for the degree of
}

MASTER OF SCIENCE, CHEMISTRY

\author{
in the faculty of Natural and Agricultural Sciences of the \\ UNIVERSITY OF PRETORIA
}

March 2004 


\title{
ANALYSIS OF COBALT, TANTALUM, TITANIUM, VANADIUM \\ AND CHROMIUM IN TUNGSTEN CARBIDE BY \\ INDUCTIVELY COUPLED PLASMA-OPTICAL EMISSION \\ SPECTROMETRY
}

\author{
by \\ Marcellé Archer \\ Promotor: \\ Prof. E.R. Rohwer \\ University of Pretoria \\ Co-Promotor: \\ Prof. R.I. McCrindle \\ Department Chemistry and Physics, \\ Tswane University of Science and Technology
}

\section{SYNOPSIS}

Inductively coupled plasma-optical emission spectroscopy was used to measure the concentrations of cobalt, tantalum, titanium, vanadium and chromium in solutions of turgsten carbide. The main advantage of the method described here lies in the speed, convenience and effectiveness of the dissolution procedure. Aliquots of powdered tungsten carbide are dissolved in 5\% aqua regia in $30 \%$ hydrogen peroxide. Complete dissolution was usually achieved within 10 minutes. The accuracy and precision of this novel method was assessed by the analysis of certified reference materials, secondary reference materials and matrix spiking. The method was successfully applied to commercial type samples with differing compositions. 


\section{SAMEVATTING}

Induktief gekoppelde plasma-optiese emissie spektrometrie is gebruik om die konsentrasie van kobalt, tantaal, titaan, vanadium en chroom in oplossings van wolframkarbied te bepaal. Die hoofvoordeel van die metode wat hier beskryf word, is die spoed, gemak en doeltreffendheid van die monstervoorbereiding. Verpoeierde wolframkarbied monsters het gewoonlik binne 10 minute opgelos na die byvoeging van ' $\mathrm{n}$ mengsel bestaande uit $5 \%$ aqua regia in $30 \%$ waterstofperoksied. Die akkuraatheid en presisie van hierdie nuwe metode is ondersoek deur gesertifiseerde verwysingsmateriale en sekondêre verwysingsmateriale te ontleed, asook deur matrysbyvoegings. Die metode is suksesvol toegepas op kommersieële monsters met verskillende samestellings. 


\section{ACKNOWLEDGEMENTS}

This study was undertaken as part of a project by the former Analytical Services group of the

Division of Material Science and Technology, CSIR.

The help and encouragement of Prof Silvana Luyckx of the University of the Witwatersrand and Virginia de Klerk, formerly of the CSIR, are gratefully acknowledged.

I also wish to thank the National Metrology Laboratory of the CSIR for their support during the later stages of the project.

I am especially grateful to my husband, Christo Kriek and my daughter, Laura, for their understanding and support throughout my studies. 


\section{CONTENTS}

CHAPTER 1: INTRODUCTION

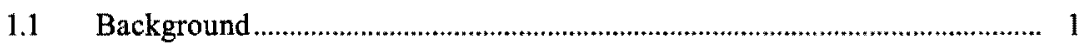

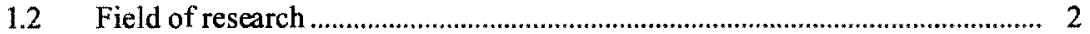

1.3 Hypothesis ......................................................................................................... 3

1.4 Objectives .................................................................................................... 4

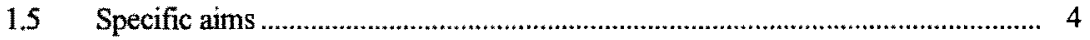

\section{CHAPTER 2: ANALYTICAL METHODS FOR TUNGSTEN CARBIDE POWDERS}

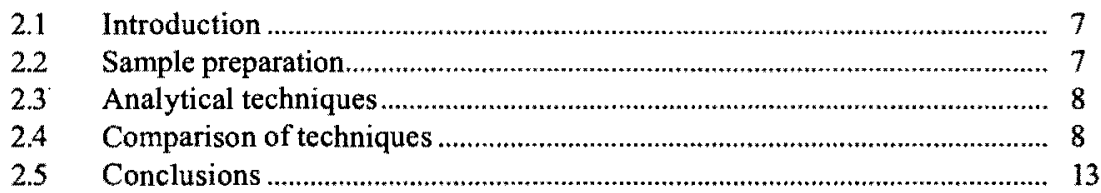

\section{CHAPTER 3: THE PRODUCTION OF TUNGSTEN CARBIDE}

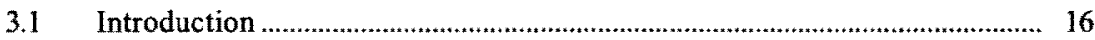

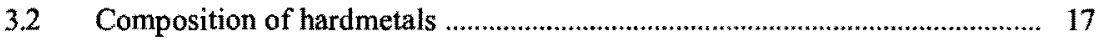

3.3 Production of tungsten metal.................................................................... 18

3.4 Carbon powder ................................................................................................ 19

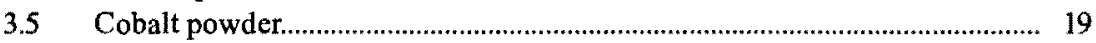

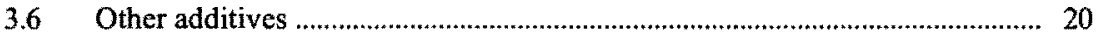

3.7 Tungsten carbide powder (WC) .............................................................. 22

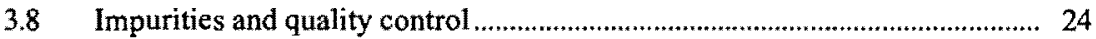

\section{CHAPTER 4: DISSOLUTION OF TUNGSTEN CARBIDE POWDERS}

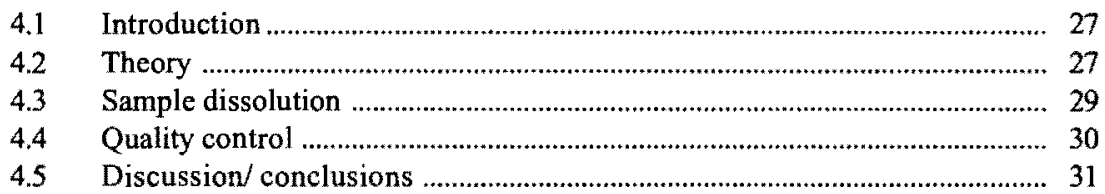

\section{CHAPTER 5: INSTRUMENTATION}

5.1 Introduction ..........

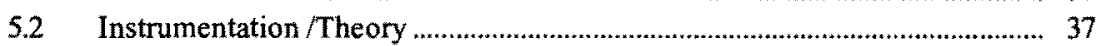

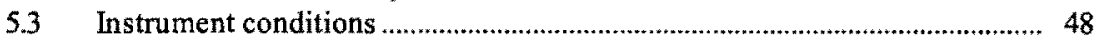

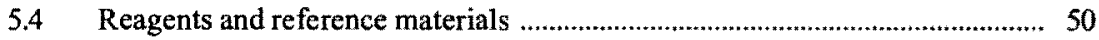

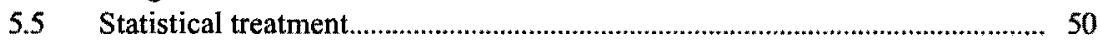

\section{CHAPTER 6: MEASUREMENT OF COBALT}

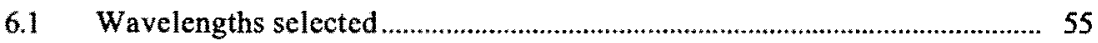

6.2 Investigation of matrix effects and interferences ......................................... 55

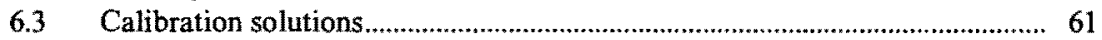

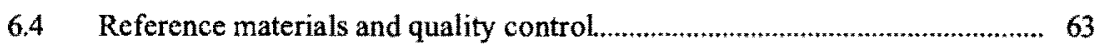

6.5 Discussion and conclusions ..................................................................69 


\section{CONTENTS}

CHAPTER 7: MEASUREMENT OF TANTALUM

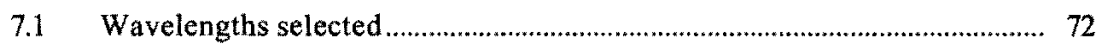

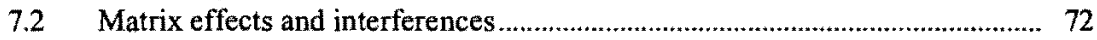

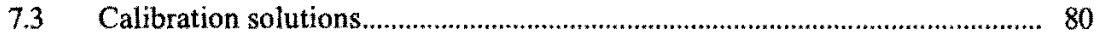

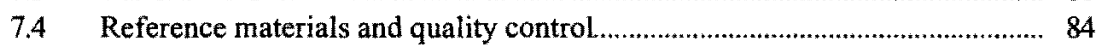

7.5 Discussion and conclusions .................................................................... 90

CHAPTER 8: MEASUREMENT OF TITANIUM

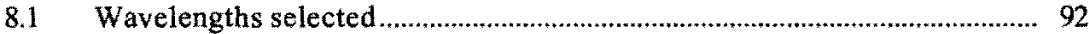

8.2 Matrix effects and interferences .................................................................. 92

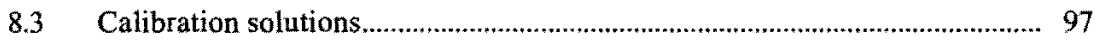

8.4 Reference materials and quality control...................................................... 99

8.5 Discussion and conclusions ................................................................ 102

CHAPTER 9: MEASUREMENT OF VANADIUM

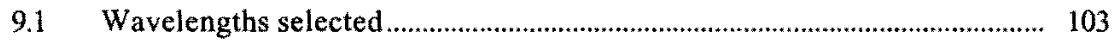

9.2 Matrix effects and interferences ................................................................ 104

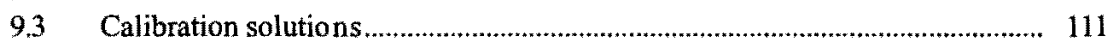

9.4 Reference materials and quality control.................................................. $\quad 113$

9.5 Discussion and conclusions ............................................................... 117

CHAPTER 10: MEASUREMENT OF CHROMIUM

10.1 Wavelengths selected ................................................................................ 120

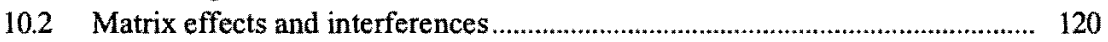

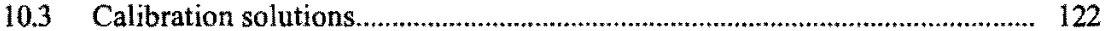

10.4 Reference materials and quality control.................................................. 125

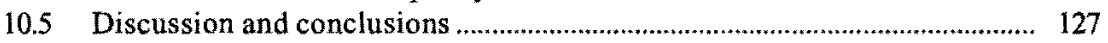

CHAPTER 11: CONCLUSION

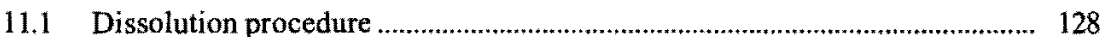

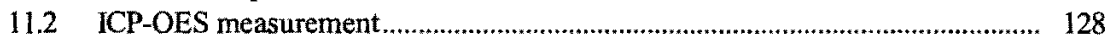

11.3 Accuracy and precision ......................................................................... 130

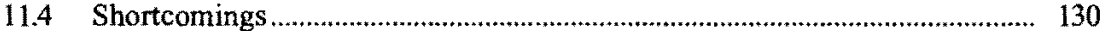

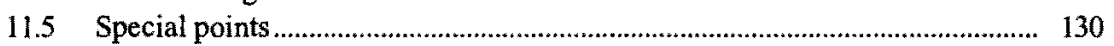

11.6 Recommendations and further research ...................................................... 131 


\section{LIST OF TABLES}

Table 3.1: Standards for hardmetal tools tips (Brookes, 1979)

Table 3.2: Changes occurring during the reduction of tungsten oxide (Luyckx, 1997)

Table 3.3: European data for the characteristics of starting materials and intermediate products (Luyckx, 1997))

Table 3.4: Limits of impurities in raw materials (Luyckx, 1997) ....................................................... 26

Table 4.1: Measurement results after aqua regia/ hydrogen peroxide dissolution of

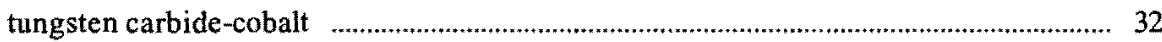

Table 6.1: Analytical solution composition for the analysis of cobalt in tungsten carbide ................ 62

Table 6.2: Preparation of Co calibration reference solutions ............................................................... 63

Table 6.3: Analytical results for cobalt in cemented carbide NBS 889 ............................................. 64

Table 6.4: Single factor ANOVA analysis on cobalt results for two wavelengths .............................6.6 66

Table 6.5: ANOVA analysis of typical results for a between-sample QC solution of $10 \mathrm{mg} / \ell$ cobalt over a period of approximately 90 minutes.

Table 6.6: Within-run repeatability of sample measurements for cobalt in tungsten carbide 69

Table 7.1: Analytical solution for the analysis of tantalum in tungsten carbide. 83

Table 7.2 Preparation of tantalum calibration solutions, matrix matched w.r.t. Co 84

Table 7.3: Measurement of tantalum without matrix matching at different wavelengths 86

Table 7.4: Two factor ANOVA analysis of tantalum results obtained by two different measurement methods 89

Table 8.1: Solution for the analysis of titanium in tungsten carbide 97

Table 8.2: Preparation of titanium calibration reference solutions......................................................... 98

Table 8.3: Measured effect of $\mathrm{W}, \mathrm{Co}, \mathrm{Cr}, \mathrm{Ta}$ and $\mathrm{V}$ on titanium measurements .................................... 99

Table 8.4: Ti measurement results for cemented carbide NBS 889 ...................................................... 100

Table 9.1: Summary of analytical solution composition during the analysis of vanadium in tungsten carbide

Table 9.2: Preparation of vanadium calibration reference solutions.

Table 9.3: Analysis of solutions of cemented carbide, NBS 889, spiked with vanadium.

Table 9.4: ICP-OES vanadium measurement results for a tungsten carbide sample previously measured by XRF

Table 9.5: Results of ICP-OES analysis by the method of standard additions.

Table 10.1: Summary of potential interferences in chromium analysis by ICP-OES..

Table 10.2: Summary of solution for the analysis of chromium in tungsten carbide

Table 10.3: Summary of the preparation of a series of chromium calibration solutions

Table 10.4: Summary of the alternative preparation of a series of chromium calibration solutions

Table 10.5: Effect of different analytical wavelengths on the calculated chromium concentration

Table 11.1: Summary of data obtained by ICP-OES measurements 


\section{LIST OF FIGURES}

Figure 3.1: British Hard Metal Association (BHMA) numerical coding system

for hardmetal properties 22

Figure 3.2: Simplified flow chart for the production of carbide powders (Brookes, 1979) ................... 23

Figure 5.1: Schematic diagram of an atomic emission system (Tissue, 1996) ...................................... 36

Figure 5.2: The Jobin Yvon inductively coupled plasma-optical emission spectrometer .................. 37

Figure 5.3: Schematic of a Czerny-Tumer mounting. .................................................................... 39

Figure 5.4: Diffraction grating separating two wavelengths of light ...................................................40

Figure 5.5: Schematic of the Jobin Yvon demountable torch and holder ............................................... 42

Figure 5.6: Representation of a plasma in an ICP torch ...................................................................... 43

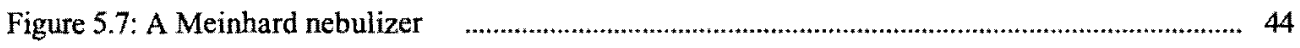

Figure 5.8: The Scott double pass spray chamber ..................................................................................... 45

Figure 5.9: Jobin Yvon sample introduction system ........................................................................ 47

Figure 5.10: Photocathode, dynode and anode layout of a photomultiplier tube................................. 48

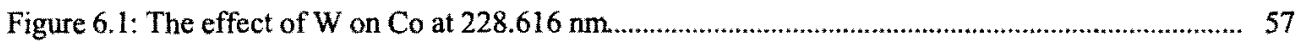

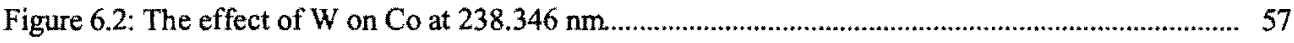

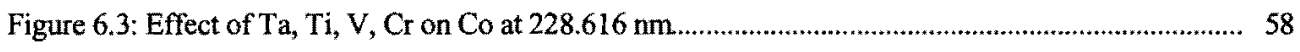

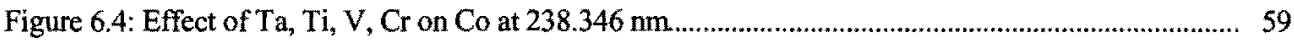

Figure 6.5: Effect of $\mathrm{W}$ on $\mathrm{Co}, \mathrm{Ta}, \mathrm{Ti}, \mathrm{Cr}$ at the $\mathrm{Co}$ emission wavelength $228.616 \mathrm{~nm}$.......................60

Figure 6.6: Effect of $\mathrm{W}$ on $\mathrm{Co}, \mathrm{Ta}, \mathrm{Ti}, \mathrm{Cr}$ at the $\mathrm{Co}$ emission wavelength $238.346 \mathrm{~nm}$........................ 60

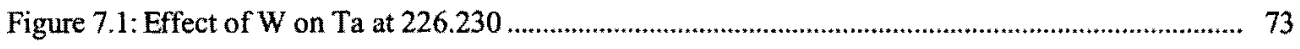

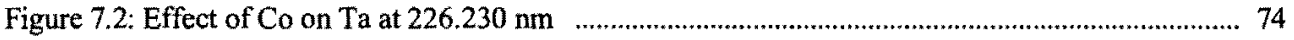

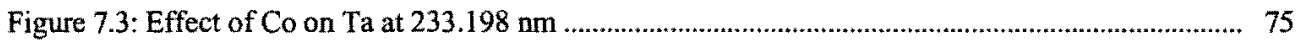

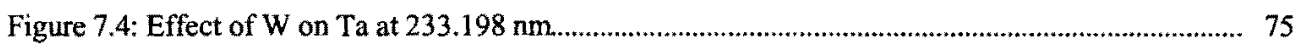

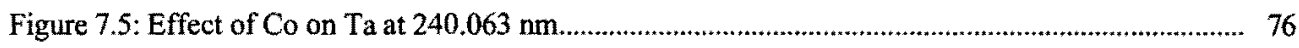

Figure 7.6: Effect of $\mathrm{W}$ on $\mathrm{Ta}$ at $240.063 \mathrm{~nm}$

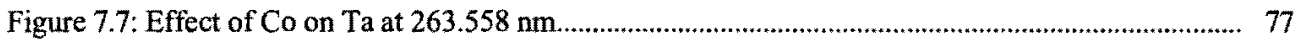

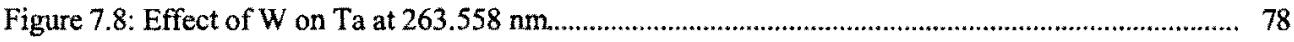

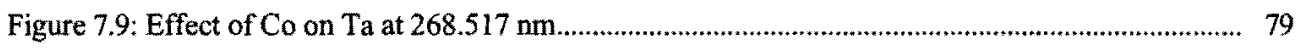

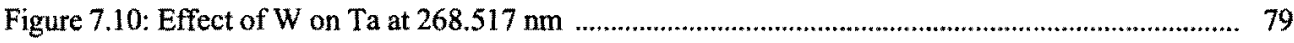

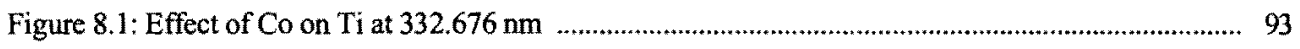

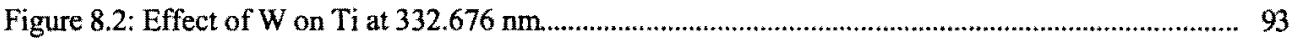

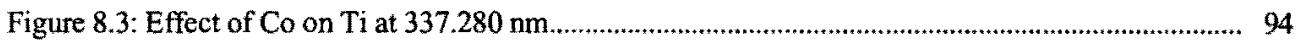


Page

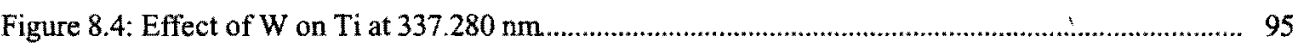

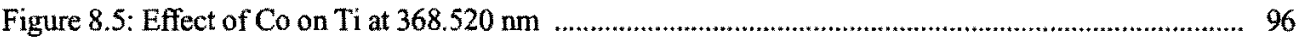

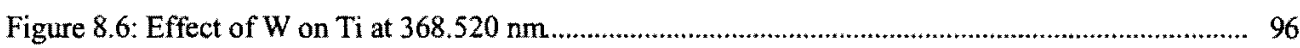

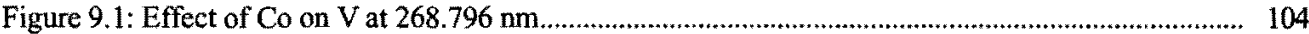

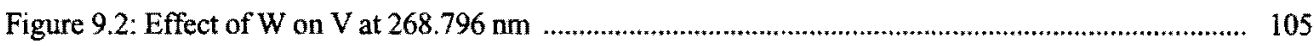

Figure 9.3: Effect of Co on V at 270.094 nm........................................................................................ 106

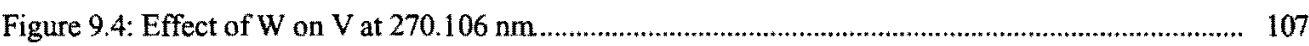

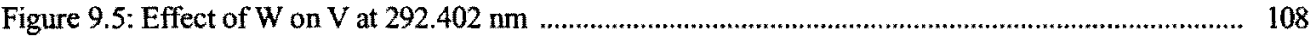

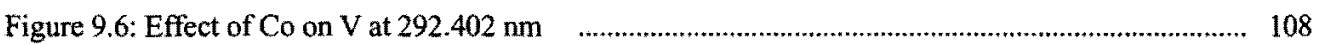

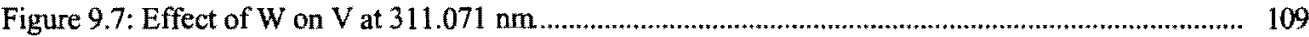

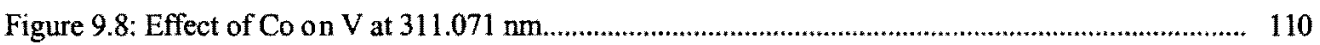

Figure 9.9: The effect of the matrix of an actual tungsten carbide sample on the

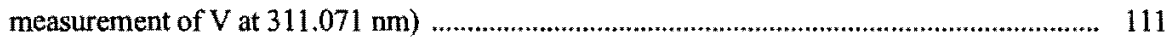

Figure 10.1: Effect of $\mathrm{W}$ and $\mathrm{Co}$ at various $\mathrm{Cr}$ emission lines .......................................................... 121

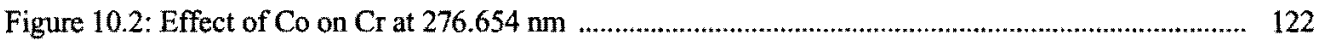

\section{APPENDICES}

Appendix 1: Properties of sintered carbides (Brookes, 1979)

Appendix 2: Tables of typical carbide grades for machining and tables of the historical developments of sintered carbides

Appendix 3: Certificate of analysis: standard reference material 889, cemented carbide

Appendix 4: Calibration data 


\section{LIST OF ABBREVIATIONS}

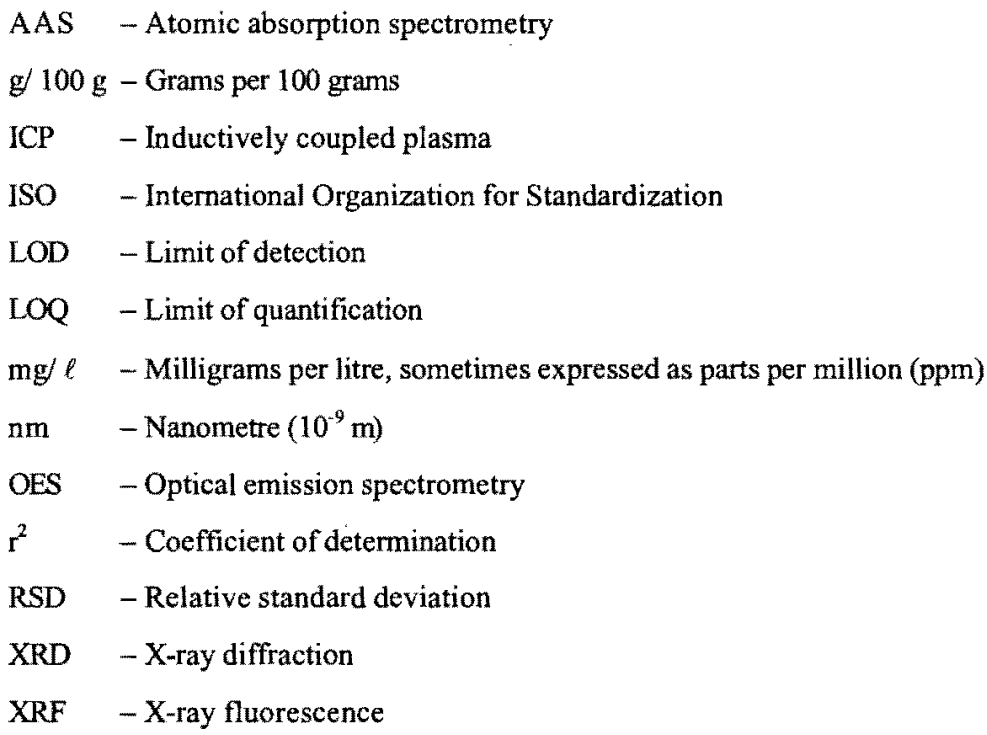

